Int. J. Electrochem. Sci., 15 (2020) $2089-2100$

International Journal of

ELECTROCHEMICAL

SCIENCE

$\underline{\text { www.electrochemsci.org }}$

\title{
Combined Effect of Cathodic Potential and Heat Treatment on Stress Corrosion Cracking Behaviour of Low Alloy Steel in Artificial Seawater
}

\author{
Daixun Jiang ${ }^{1}$, Jiangfeng An ${ }^{2,3}$, Jun $W u^{2,3, *}$, Penghua Zheng ${ }^{2,3}$ \\ ${ }^{1}$ CRRC Qingdao Sifang Co. Ltd, No.88 Jinhongdong Road, Qingdao, 266111, China \\ ${ }^{2}$ Wuhan Research Institute of Materials Protection Co., Ltd, 126 Bao Feng Erlu, Wuhan, Hubei \\ 430030, China \\ ${ }^{3}$ Wuhan Materials Corrosion of Atmospheric Environment National Observation and Research Station, \\ 6 Jin Tan lu, Wuhan, Hubei 430030, China \\ *E-mail: cbswuj@sina.com
}

doi: $10.20964 / 2020.03 .67$

Received: 4 November 2019 / Accepted: 12 January 2020 / Published: 10 February 2020

In this study, the SCC behaviour and mechanism of E690 steels with different heat treatments were investigated in artificial seawater by slow strain rate test, surface analysis technique and potentiodynamic polarization curve test. The results show that the SCC behaviour of E690 steel is mainly controlled by anodic dissolution, and the steels after tempering show the high SCC susceptibilities because of the high corrosion current densities. As the cathodic potential negatively decreases to $-850 \mathrm{mV}$, the SCC susceptibility of base metal decreases; however, the SCC susceptibilities of the steels after tempering increase. At $-1050 \mathrm{mV}$, the SCC susceptibilities of the steels with different heat treatments increase. And the SCC susceptibilities of the steels after tempering are higher than those of base metal at various potentials. The phenomenon is related to the high hydrogen embrittlement susceptibilities of the steels after tempering compared to that of the base metal.

Keywords: Low alloy steel; Heat treatment; Cathodic potential; Stress corrosion cracking

\section{FULL TEXT}

(C) 2020 The Authors. Published by ESG (www.electrochemsci.org). This article is an open access article distributed under the terms and conditions of the Creative Commons Attribution license (http://creativecommons.org/licenses/by/4.0/). 